\title{
User Behavioral Intention to Use Online Distance Learning (ODL): The Role of Self-Efficacy and Domain Knowledge
}

\author{
https://doi.org/10.3991/ijim.v15i18.24539 \\ Mohamad Rahimi Mohamad Rosman ${ }^{(凶)}$, Izzatil Husna Arshad, Mohamad Sayuti Md \\ Saleh, Nurulannisa Abdullah, Faizal Haini Fadzil, Mohd Zafian Mohd Zawawi \\ Universiti Teknologi MARA Kelantan Branch, Kelantan, Malaysia \\ rahimimr@uitm.edu.my
}

\begin{abstract}
The rise of novel coronavirus 2019 has shifted the roles of education industry. Face-to-face have become a distant memory; students and educators are now heavily relying on the digital communication. Application such as Google Meet, Webex, Webinar, Stream Yard, Zoom, and many more have become the new norm among educators and students. However, the sudden dependency on the digital technologies raises a question on the user intention to use this new digital technology. Therefore, the objective of this study is to determine the role of self-efficacy and domain knowledge towards user behavioral intention to use online distance learning. An instrument was developed by adopting to previous instruments and was analyze using Statistical Package for Social Science and SmartPLS for inferential analysis. Findings shows that the exogenous variables are capable to explained between $47.8 \%$ to $68.1 \%$ of the endogenous variables.
\end{abstract}

Keywords - online distance learning, domain knowledge, self-efficacy, behavioral intention

\section{Introduction}

COVID-19 stands for coronavirus disease and is referred to as the new coronavirus or '2019-nCoV' for 2019. On 11 March 2020, the World Health Organization (WHO) classified COVID-19 as a global pandemic [1]. Because of COVID-19, thousands of school closures are being enforced worldwide. In April 2020, UNESCO [2] announced that $1,576,021,818$ students in 188 countries were affected at all levels of learning.

Among the Southeast Asian countries, Malaysia has reported a high number of COVID-19 positive cases [3]. On March 18, 2020, the Movement Control Order (MCO) was enacted in Malaysia [3]. The Minister of Health issued a set of regulations under the Prevention and Control of Infectious Diseases Act 1988 (the Act) as urgent measures to combat the spread of the Corona Virus. The MCO not only restricts movement, but has enforced the closure, whether public or private, of all non-essential premises, including kindergartens, schools, colleges, and universities. 
Stopping all educational activities and sending their students home was the immediate response of universities and other higher education institutions. The closing of universities has contributed to the introduction of creative education approaches to ensure continuing education for students [4]. Universities are expected to turn to online forms of teaching and learning activities. With social distancing standards, all face-toface classes have been suspended [5]. Online learning was widely promoted to replace conventional face-to-face learning [6].

A portfolio of learning strategies and materials that can cater to the various needs of learners across a range of learning environments needs to be created [7]. Several studies have also found challenges posed by online learning to students during MCO [8]. Many university students are not prepared for that mode. They lack knowledge on user behavioural intention to use or engage with Online Distance Learning (ODL). The performance of the online learning depends not only on the acceptance of the use of the technology, but also on the user's technology readiness and its self-efficacy on the Internet [9].

Therefore, due to the obvious challenges of ODL, this paper seeks to examine the relationship between self-efficacy, domain knowledge, perceived usefulness, perceived ease of use, attitude towards ODL and behavioural intention to use ODL in higher education to provide students, lecturers, and faculty management with a deeper understanding of future teaching and course development planning.

\section{Research model}

Figure 1 shows the research model of the study, adopted from Technology Acceptance Model [10]. There are a total of 6 variables altogether. A total of 7 hypothesis were formulated and subsequently explain below.

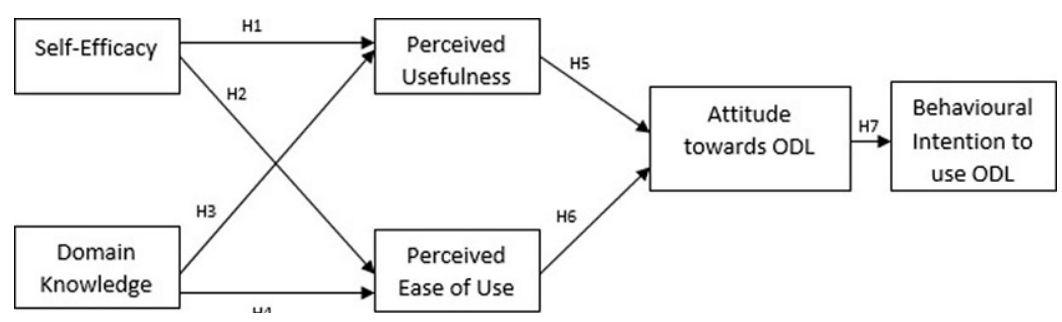

Fig. 1. Model for paper

TAM which proposed by Davis [10] highlighted that external factors may affect purpose and actual use through mediated effects on perceived usefulness and perceived ease of use. One of the factors emphasized by this study is domain knowledge. Das [11] pointed out that the way domain knowledge is structured in its computer incorporation aids knowledge collection.

Domain knowledge (an element of user personal infrastructure) also revealed as one of the key factors affecting information retrieval (IR) system use [12]. Furthermore, Ahmed Younis Alsabawy, Cater-Steel and Soar [13] stated that to ensure high quality of service delivery, two factors should be considered, consisting of system 
and information quality. Information quality which related to domain knowledge is a critical element in measuring e-learning system success. F. Mohammadi, A. Abrizah, M. Nazari [14] studied teachers' perceptions of information quality in Farsi Web-based Learning Resources and highlighted 14 indicators of characteristic which indicated that information quality could reflect in measuring the success of information systems. Meanwhile Roca, Chiu, and Martínez [15] identified that that information quality had significant effects on user satisfaction, which directly affected the user's intention to use e-learning systems.

Arbaugh [16] stated that perceived usefulness of the e-learning would improve the attitude of students toward learning experience and students' consideration to enrol into online courses in future. E-learning users believe to accept useful educational services with high quality, whereby a secure environment of e-learning systems can contribute to support perceived usefulness. This includes security in information exchange between users, educational materials usage, and provision of respond to students' enquiries [13]. Thus, the ability of e-learning to support safe and secure environment may affect users' attitude towards ODL initiative. Likewise, Cerezo, et al. [17] highlighted that perceived usefulness may increase motivation for the learning task.

Volery and Lord [18] examined critical success factors in online education and found out that quality of a system was a key factor in measuring online education according two indicators: ease of access in navigation and interface. In addition, Tella [19] used seven indicators to evaluate e-learning system quality which comprise of availability, easy to use, user-friendly, interaction, accessibility, attractive features, and presentation. Furthermore, Eom and Stapleton [20] emphasized system quality as a system which possesses distinguishing characteristics which evaluated response time, systems accessibility, system reliability, systems flexibility, systems usefulness, ease of use, ease of learning, etc.

Chiu and Wang [21] stated that intrinsic values are significant predictors of students' intentions to continuously participate in e-learning. According to Muhammad Faizal Samat, Nur Amalina Awang, Siti Nor Adawiah Hussin, and Farahiyah Akmal Mat Nawi [22], selection of ODL platforms and tools should consider on healthy emotional state to ensure educators and learners could have intention to explore the technologies provided. Similarly, Khechine, Raymond and Augier [23] pointed out that intrinsic value is the significant contributor in the estimating behavioural intention and use behaviour in the context of ODL adoption. Therefore, based on the above arguments, the following are the hypothesis of the study:

H1: Self-efficacy has a positive and significant relationship with perceived usefulness.

$\mathrm{H} 2$ : Self-efficacy has a positive and significant relationship with perceived ease of use.

H3: Domain knowledge has a positive and significant relationship with perceived usefulness.

H4: Domain knowledge has a positive and significant relationship with perceived ease of use.

H5: Perceived usefulness has a positive and significant relationship with attitude towards ODL.

H6: Perceived ease of use has a positive and significant relationship with attitude towards ODL. 
H7: Attitude towards ODL has a positive and significant relationship with behavioural intention to use ODL.

\section{Methodology}

The conduct of this study is quantitative using questionnaire. An instrument was developed based on previous research and validated based on pre-test among experts. The selection of experts based on the following criteria: (1) academic qualification, (2) academic experience, (3) expertise within the field of Information System (IS). The expert review process took 2 weeks before the instrument was sent back to the researchers. The instrument was modified based on the recommendation and suggestion from the experts. Next, face validity was conducted. A total of 10 respondents were chosen from the Faculty of Information Management, Universiti Teknologi MARA Cawangan Kelantan. These respondents were excluded from the total sampling. Pilot test of instrument was carried out to determine the reliability of the instrument. A total of 60 respondents involves in the pilot test. The following Table 1 shows the results of the reliability analysis. The result of the Cronbach's alpha shows a value ranging from 0.770 to 0.963 , indicating a sufficient result to confirm the reliability of the instrument as suggested by Nunnally [24].

Table 1. Reliability analysis of pilot study assessment

\begin{tabular}{|l|c|c|}
\hline \multicolumn{1}{|c|}{ Construct } & Items & Cronbach Alpha \\
\hline SEF & 5 & 0.770 \\
\hline DOK & 4 & 0.873 \\
\hline PEU & 4 & 0.910 \\
\hline EOU & 3 & 0.900 \\
\hline ATT & 3 & 0.924 \\
\hline BIU & 3 & 0.963 \\
\hline
\end{tabular}

The respondent of the study was selected based on convenience sampling. The respondents were chosen based on the following criteria: (1) undergraduate students enrolled with Universiti Teknologi MARA Cawangan Kelantan, (2) Students status currently active, and (3) enrolled for at least one subject that utilize ODL for the current semester. An invitation email was sent to undergraduate students that meet the criteria; a total of 524 valid responses were received. Data were coded, perform data cleaning, before analysis using SPSS and SmartPLS. The subsequent section describes the findings of the study.

\section{$4 \quad$ Results and findings}

The following Table 2 shows the demographic profile of the respondents. A total of 524 respondents have responded the survey. The gender profile showed $77.3 \%(n=405)$ of respondents are female, while $22.7 \%(\mathrm{n}=119)$ are male. The age of respondent is mostly between $20-30$ years $(n=354$ or $67.6 \%)$, below $20(n=164$ or $31.3 \%), 31-50$ $(n=5$ or $1.0 \%)$ and above $50(n=1$ or $0.2 \%)$. 
From the locality perspective, most respondents are from Kelantan ( $\mathrm{n}=240$ or $45.8 \%$ ), Terengganu $(n=65$ or $12.4 \%)$, Pahang $(n=53$ or $10.1 \%)$, Selangor $(n=52,9.9 \%)$, Kedah $(n=29$ or $5.5 \%)$, Perak $(n=25$ or $4.8 \%)$, Johor $(n=19,3.6 \%)$, Kuala Lumpur $(n=13$ or $2.5 \%)$, Pulau Pinang ( $\mathrm{n}=11$ or $2.1 \%)$, Negeri Sembilan $(\mathrm{n}=8$ or $1.5 \%)$, Melaka $(\mathrm{n}=5$ or $1.0 \%)$, Perlis $(n=3$ or $0.6 \%)$, and Sabah $(n=1$ or $0.2 \%)$.

From the context of faculty, a total of $47.5 \%(n=249)$ respondents are from Faculty of Information Management, follow with Faculty of Business and Management 26.1\% $(\mathrm{n}=137)$, Faculty of Administrative Science and Policy Studies 11.3\% ( $\mathrm{n}=59)$, Faculty of Accountancy 5.7\% ( $\mathrm{n}=30)$, Faculty of Art and Design $5.0 \%(\mathrm{n}=26)$, and Faculty of Computer and Mathematical Science 4.4\% $(n=23)$. All the respondent divided into $67.2 \%(n=352)$ diploma level, $31.7 \%(n=166)$ of degree, and others $1.1 \%(n=6)$.

Table 2. Demographic profile

\begin{tabular}{|c|c|c|c|}
\hline Item & & Frequency & $\%$ \\
\hline \multirow[t]{2}{*}{ Gender } & Male & 119 & 22.7 \\
\hline & Female & 405 & 77.3 \\
\hline \multirow[t]{4}{*}{ Age } & Below 20 & 164 & 31.3 \\
\hline & $20-30$ & 354 & 67.6 \\
\hline & $31-50$ & 5 & 1.0 \\
\hline & $>50$ & 1 & 0.2 \\
\hline \multirow[t]{13}{*}{ State } & Kelantan & 240 & 45.8 \\
\hline & Terengganu & 65 & 12.4 \\
\hline & Pahang & 53 & 10.1 \\
\hline & Kedah & 29 & 5.5 \\
\hline & Perlis & 3 & 0.6 \\
\hline & Pulau Pinang & 11 & 2.1 \\
\hline & Kuala Lumpur & 13 & 2.5 \\
\hline & Selangor & 52 & 9.9 \\
\hline & Negeri Sembilan & 8 & 1.5 \\
\hline & Melaka & 5 & 1.0 \\
\hline & Johor & 19 & 3.6 \\
\hline & Sabah & 1 & 0.2 \\
\hline & Perak & 25 & 4.8 \\
\hline \multirow[t]{6}{*}{ Faculty } & Faculty of Information Management & 249 & 47.5 \\
\hline & Faculty of Administrative Science and Policy Studies & 59 & 11.3 \\
\hline & Faculty of Business and Management & 137 & 26.1 \\
\hline & Faculty of Accountancy & 30 & 5.7 \\
\hline & Faculty of Computer and Mathematical Sciences & 23 & 4.4 \\
\hline & Faculty of Art and Design & 26 & 5.0 \\
\hline \multirow{3}{*}{$\begin{array}{l}\text { Level of } \\
\text { study }\end{array}$} & Diploma & 352 & 67.2 \\
\hline & Degree & 166 & 31.7 \\
\hline & Others & 6 & 1.1 \\
\hline
\end{tabular}


Table 3 shows the result of the measurement model analysis. A total of 2 runs was conducted. During the initial run, all indicators meet the expected value as suggested by Hair, Sarstedt, Hopkins, and G. Kuppelwieser [25], except for SEF (factor loading 0.328$)$. SEF5 was removed from the initial model (4.5\%). A second run analysis shows that all factor loadings, average variance extract (AVE), Cronbach's alpha and composite reliability (CR) meet the expected threshold [25]. The factor loading for SEF between 0.628 to 0.846 (AVE 0.623, CR 0.867), DOK between 0.861 to 0.896 (AVE 0.731, CR 0.916), PEU between 0.846 to 0.917 (AVE 0.789, CR 0.937), EOU between 0.892 to 0.926 (AVE 0.834, CR 0.938), ATT between 0.914 to 0.941 (AVE 0.869 , CR 0.952), and BIU between 0.959 to 0.970 (AVE 0.931, CR 0.976). Therefore, it is assumed that convergence validity has been ascertained.

Table 3. Final assessment of convergence validity

\begin{tabular}{|c|c|c|c|c|c|}
\hline Construct & Indicators & $\begin{array}{c}\text { Factor } \\
\text { Loading }\end{array}$ & $\begin{array}{l}\text { Average Variance } \\
\text { Extract (AVE) }\end{array}$ & $\begin{array}{c}\text { Cronbach's } \\
\text { Alpha }\end{array}$ & $\begin{array}{l}\text { Composite } \\
\text { Reliability }\end{array}$ \\
\hline \multirow[t]{4}{*}{ Self-Efficacy (SEF) } & SEF1 & 0.846 & \multirow[t]{4}{*}{0.623} & \multirow[t]{4}{*}{0.795} & \multirow[t]{4}{*}{0.867} \\
\hline & SEF2 & 0.824 & & & \\
\hline & SEF3 & 0.839 & & & \\
\hline & SEF4 & 0.628 & & & \\
\hline \multirow{4}{*}{$\begin{array}{l}\text { Domain Knowledge } \\
\text { (DOK) }\end{array}$} & DOK1 & 0.861 & \multirow[t]{4}{*}{0.731} & \multirow[t]{4}{*}{0.877} & \multirow[t]{4}{*}{0.916} \\
\hline & DOK2 & 0.884 & & & \\
\hline & DOK3 & 0.775 & & & \\
\hline & DOK4 & 0.896 & & & \\
\hline \multirow{4}{*}{$\begin{array}{l}\text { Perceived } \\
\text { Usefulness (PEU) }\end{array}$} & PEU1 & 0.846 & \multirow[t]{4}{*}{0.789} & \multirow[t]{4}{*}{0.910} & \multirow[t]{4}{*}{0.937} \\
\hline & PEU2 & 0.902 & & & \\
\hline & PEU3 & 0.887 & & & \\
\hline & PEU4 & 0.917 & & & \\
\hline \multirow{3}{*}{$\begin{array}{l}\text { Perceived Ease of } \\
\text { Use (EOU) }\end{array}$} & EOU1 & 0.892 & \multirow[t]{3}{*}{0.834} & \multirow[t]{3}{*}{0.900} & \multirow[t]{3}{*}{0.938} \\
\hline & EOU2 & 0.926 & & & \\
\hline & EOU3 & 0.921 & & & \\
\hline \multirow{3}{*}{$\begin{array}{l}\text { Attitude Towards } \\
\text { ODL (ATT) }\end{array}$} & ATT1 & 0.941 & \multirow[t]{3}{*}{0.869} & \multirow[t]{3}{*}{0.924} & \multirow[t]{3}{*}{0.952} \\
\hline & ATT2 & 0.914 & & & \\
\hline & ATT3 & 0.940 & & & \\
\hline \multirow{3}{*}{$\begin{array}{l}\text { Behavioural } \\
\text { Intention Towards } \\
\text { ODL (BIU) }\end{array}$} & BIU1 & 0.966 & \multirow[t]{3}{*}{0.931} & \multirow[t]{3}{*}{0.963} & \multirow[t]{3}{*}{0.976} \\
\hline & BIU2 & 0.959 & & & \\
\hline & BIU3 & 0.970 & & & \\
\hline
\end{tabular}


Next step is to access the model for discriminant validity. A Fornell-Larcker Criterion was conducted. The following Table 4 shows the result of the Fornell-Larcker Criterion assessment. Based on the result, the square root of the AVE is bigger compared to its previous value, therefore indicating that discriminant validity has been achieved.

Table 4. Result of Fornell-Larcker criterion

\begin{tabular}{|l|c|c|c|c|c|c|}
\hline & ATT & BIU & DOK & EOU & PEU & SEF \\
\hline ATT & $\mathbf{0 . 9 3 2}$ & & & & & \\
\hline BIU & 0.781 & $\mathbf{0 . 9 6 5}$ & & & & \\
\hline DOK & 0.612 & 0.474 & $\mathbf{0 . 8 5 5}$ & & & \\
\hline EOU & 0.818 & 0.678 & 0.677 & $\mathbf{0 . 9 1 3}$ & & \\
\hline PEU & 0.737 & 0.626 & 0.640 & 0.827 & $\mathbf{0 . 8 8 8}$ & \\
\hline SEF & 0.610 & 0.502 & 0.736 & 0.670 & 0.648 & $\mathbf{0 . 7 9 0}$ \\
\hline
\end{tabular}

The following Table 5 shows the result of a structural model analysis. The result show that all hypotheses were accepted. Self-efficacy has a significant and positive relationship with perceived usefulness (H1: Supported, $\mathrm{t}=6.947, \mathrm{p}=0.000)$ and perceived ease of use (H2: Supported, $\mathrm{t}=7.619, \mathrm{p}=0.000)$. Domain knowledge also has a positive and significant relationship with perceived usefulness (H3: Supported, $\mathrm{t}=5.855, \mathrm{p}=0.000$ ) and perceived ease of use (H4: Supported, $\mathrm{t}=7.009, \mathrm{p}=0.000)$. On the other hand, perceived usefulness has a significant and positive relationship with attitude towards ODL (H5: Supported, $t=3.429, \mathrm{p}=0.001$ ). Likewise, perceived ease of use also has a positive and significant relationship with attitude towards ODL (H6: Supported, $\mathrm{t}=12.715$, $\mathrm{p}=0.000$ ). Lastly, attitude towards ODL also has a significant and positive relationship with behavioural intention to use ODL (H7: Supported, $t=42.395, p=0.000$ ). The following Figure 2 shows the final structural model of the study.

Table 5. Relationship between variables (direct effect)

\begin{tabular}{|l|l|c|c|c|c|l|}
\hline & Relationship & Coefficient & Std. Dev. & t-Value & p-Values & \multicolumn{1}{|c|}{ Decision } \\
\hline H1 & SEF $\rightarrow$ PEU & 0.387 & 0.056 & $6.947^{* *}$ & $0.000^{* *}$ & Supported \\
\hline H2 & SEF $\rightarrow$ EOU & 0.377 & 0.049 & $7.619^{* *}$ & $0.000^{* *}$ & Supported \\
\hline H3 & DOK $\rightarrow$ PEU & 0.355 & 0.061 & $5.855^{* *}$ & $0.000^{* *}$ & Supported \\
\hline H4 & DOK $\rightarrow$ EOU & 0.401 & 0.057 & $7.009^{* *}$ & $0.000^{* *}$ & Supported \\
\hline H5 & PEU $\rightarrow$ ATT & 0.192 & 0.056 & $3.429^{* *}$ & $0.001^{* *}$ & Supported \\
\hline H6 & EOU $\rightarrow$ ATT & 0.660 & 0.052 & $12.715^{* *}$ & $0.000^{* *}$ & Supported \\
\hline H7 & ATT $\rightarrow$ BIU & 0.781 & 0.018 & $42.395^{* *}$ & $0.000^{* *}$ & Supported \\
\hline
\end{tabular}

Notes: $* \mathrm{t}>1.645, \mathrm{p}$-value $>0.05, * * \mathrm{t}>2.58, \mathrm{p}$-value $<0.01$. 


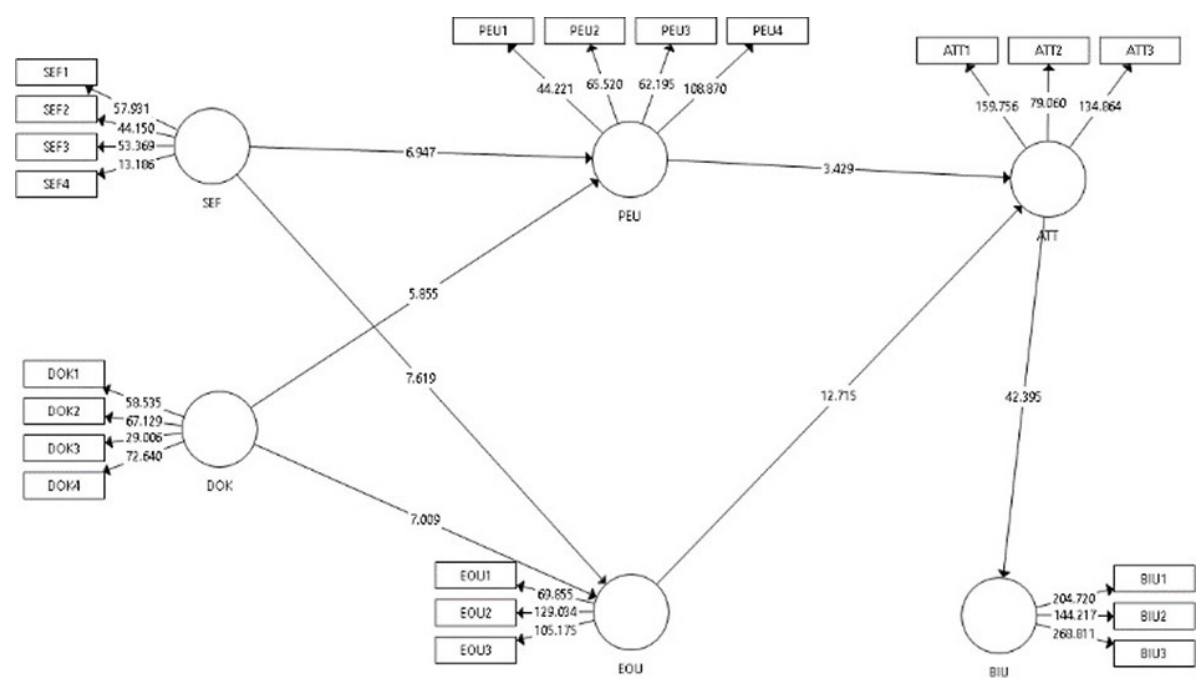

Fig. 2. Final structural model of the study

The next Table 6 shows the $\mathrm{R}^{2}$ result of study. Wherry [26] suggested that research should use the adjusted $\mathrm{R}^{2}$ instead of the regular $\mathrm{R}^{2}$ because there were some issues with regular $\mathrm{R}^{2}$. Regular $\mathrm{R}^{2}$ value increased when additional predictor constructs were included in the model. From the result shown on the Table 6 , the exogenous variables of the study were capable to explain the $68.1 \%$ (moderate), $61 \%$ (moderate), $52.3 \%$ (moderate), and $47.8 \%$ (small) from the overall variance of perceived usefulness, perceived ease of use, attitude towards ODL and behavioural intention to use ODL [27].

Table 6. Result of coefficient of determination score

\begin{tabular}{|l|c|c|l|}
\hline \multicolumn{1}{|c|}{ Construct } & R Square & R Square Adjusted & \multicolumn{1}{c|}{ Decision } \\
\hline ATT & 0.681 & 0.679 & Moderate \\
\hline BIU & 0.610 & 0.609 & Moderate \\
\hline EOU & 0.523 & 0.521 & Moderate \\
\hline PEU & 0.478 & 0.476 & Small \\
\hline
\end{tabular}

The next step is to assess the level of effect size $\left(f^{2}\right)$. Cohen [28] recommended that the $f^{2}$ values of $0.35,0.15$, and 0.02 were regarded as large, medium, and small effect sizes, respectively [29], [30], [31]. Table 7 shows the effect level of study size. It can be concluded that all constructs have an effect size ranging from 0.036 to 0.1 .565 . 
Table 7. Assessing the level of effect size $\left(f^{2}\right)$

\begin{tabular}{|l|l|l|}
\hline \multicolumn{1}{|c|}{ Relationship } & $\boldsymbol{f}^{2}$ & \multicolumn{1}{c|}{ Decision } \\
\hline ATT $\rightarrow$ BIU & 1.565 & Large \\
\hline PEU $\rightarrow$ ATT & 0.036 & Medium \\
\hline EOU $\rightarrow$ ATT & 0.430 & Large \\
\hline $\mathrm{SEF} \rightarrow$ PEU & 0.132 & Small \\
\hline SEF $\rightarrow$ PEU & 0.135 & Small \\
\hline DOK $\rightarrow$ EOU & 0.111 & Small \\
\hline DOK $\rightarrow$ EOU & 0.155 & Medium \\
\hline
\end{tabular}

\section{Conclusion}

The study has investigated and identified the user behavioural intention to use Online Distance Learning (ODL). The study seeks to examine the relationship between self-efficacy, domain knowledge, perceived usefulness, perceived ease of use, attitude towards ODL and behavioural intention to use ODL in higher education to provide students, lecturers, and faculty management with a deeper understanding of future teaching and course development planning.

The result show that all hypotheses were accepted. The investigation led to identifying the role of self-efficacy and domain knowledge towards ODL since all students involved in online studies due to the changes of teaching and learning methods during Covid-19 pandemic. The study conducted based on convenience sampling of Faculty of Information Management, Universiti Teknologi MARA Cawangan Kelantan only and it may not be representative of the whole university.

The study has contributed to the effectiveness for online teaching and learning method used during COVID-19 pandemic as precaution actions to ensure schools and academic institutions can continue its operation in the education system. The implication of this study will be beneficial for the university to engage programs for successful implementation towards adopting Online Distance Learning (ODL).

\section{Acknowledgement}

This research work is supported by the Research Management Centre (RMC), Universiti Teknologi MARA Kelantan Branch under Special Interest Group (SIG) fund.

\section{$7 \quad$ References}

[1] Cucinotta, D., \& Vanelli, M. (2020). WHO declares COVID-19 a pandemic. Acta Bio-Medica: Atenei Parmensis, 91(1), 157-160.

[2] UNESCO (2020). Global Monitoring of School Closures caused by COVID-19. Retrieved from https://en.unesco.org/covid19/educationresponse 
[3] Ganasegeran, K., Ch'ng, A., \& Looi, I. (2020). COVID-19 in Malaysia: Crucial measures in critical times. Journal of Global Health, 10(2), 020333. https://doi.org/10.7189/ jogh. 10.020333

[4] Bolatov, A. K., Seisembekov, T. Z., Askarova, A. Z., Baikanova, R. K., Smailova, D. S., \& Fabbro, E. (2020). Online-learning due to COVID-19 improved mental health among medical students. Med Sci Educ, 1-10. https://doi.org/10.1007/s40670-020-01165-y

[5] Agarwal, S., \& Kaushik, J. S. (2020). Student's perception of online learning during COVID pandemic. Indian J Pediatr, 87(7), 554. doi: https://doi.org/10.1007/s12098-020-03327-7

[6] Dong, C., Cao, S., \& Li, H. (2020). Young children's online learning during COVID-19 pandemic: Chinese parents' beliefs and attitudes. Child Youth Serv Rev, 118, 105440. https://doi.org/10.1016/j.childyouth.2020.105440

[7] Chiam Chooi, C., Woo Tai, K., Chung Han, T., \& Kumar, K. P. N. P. R. (2017). The behavioural intention to use video lecture in an ODL institution: Insights from learners' perspective. Asian Association of Open Universities Journal, 12(2), 206-217. https://doi .org/10.1108/AAOUJ-09-2017-0030

[8] Hashim, H., Kadir, N. A. A., Mansor, F., \& Azudin, M. Z. M. (2020). Open and distance learning (ODL) during movement control order (MCO): Conceptualising the relationships between self-efficacy, learning motivation and performance of higher learning education students. International Journal of Academic Research in Business and Social Sciences, 10(8), 258-269. https://doi.org/10.6007/IJARBSS/v10-i8/7530

[9] Lai, M.-L. (2008). Technology readiness, Internet self-efficacy and computing experience of professional accounting students. Campus-Wide Information Systems, 25(1), 18-29. https:// doi.org/10.1108/10650740810849061

[10] Davis, F. D. (1989). Perceived usefulness, perceived ease of use, and user acceptance of information technology. MIS Quarterly, 13(3), 319-339. https://doi.org/10.2307/249008

[11] Das, A. (2003). Knowledge representation. In Encyclopedia of Information Systems, 33-41. Retrieved from: https://doi.org/10.1016/B0-12-227240-4/00102-7

[12] Xie, I., \& Matusiak, K. K. (2016). User needs and search behaviors. In Discover Digital Libraries, 231-253. https://doi.org/10.1016/B978-0-12-417112-1.00008-9

[13] Ahmed, Y. A., Cater-Steel, A., \& Soar, J. (2016). Determinants of perceived usefulness of e-learning systems. Computers in Human Behavior, 64, 843-858. https://doi.org/10.1016/j .chb.2016.07.065

[14] Mohammadi, F., Abrizah, A., \& Nazari, M. (2015). Is the information fit for use? Exploring teachers perceived information quality indicators for Farsi web-based learning resources. Malaysian Journal of Library \& Information Science, 20(1), 99-122.

[15] Roca, J. C., Chiu, C. M., \& Martínez, F. J. (2006). Understanding e-learning continuance intention: An extension of the technology acceptance model. International Journal of Human-Computer Studies, 64(8), 683-696. https://doi.org/10.1016/j.ijhcs.2006.01.003

[16] Arbaugh, J. B. (2000). How classroom environment and student engagement affect learning in Internet-based MBA courses. Business Communication Quarterly, 63(4), 9-26. https:// doi.org/10.1177/108056990006300402

[17] Cerezo, et al. (2019). Mediating role of self-efficacy and usefulness between self-regulated learning strategy knowledge and its use. Revista de Psicodidáctica, 1, 1-8. https://doi .org/10.1016/j.psicod.2018.08.001; https://doi.org/10.1016/j.psicoe.2018.09.001

[18] Volery, T., \& Lord, D. (2000). Critical success factors in online education. International Journal of Educational Management, 14(5), 216-223. https://doi.org/10.1108/09513540010344731

[19] Tella, A. (2011). Reliability and factor analysis of a blackboard course management system success: A scale development and validation in an educational context. Journal of Information Technology Education, 10, 53-78. https://doi.org/10.28945/1368 
[20] Eom, S. B., \& Stapleton, J. (2011). Testing the delone-mclean model of information system success in an e-learning context. In S. B. Eom, \& J. B. Arbaugh (Eds.), Student satisfaction and learning utcomes in e-learning: An introduction to empirical research (pp. 82-109). The United States of America: IGI Global. https://doi.org/10.4018/978-1-60960-615-2.ch005

[21] Chiu, C. M., \& Wang, E. T. G. (2008). Understanding web-based learning continuance intention: The role of subjective task value. Information \& Management, 45(3), 194-201. https://doi.org/10.1016/j.im.2008.02.003

[22] Samat, M. F., Awang, N. A., Hussin, S. N. A., \& Nawi, F. A. M. (2020). Online distance learning amidst covid-19 pandemic among university students: a practicality of partial least squares structural equation modelling approach. Asian Journal of University Education, 16(3), 220-233. https://doi.org/10.24191/ajue.v16i3.9787

[23] Khechine, H., Raymond, B., \& Augier, M. (2020). The adoption of a social learning system: Intrinsic value in the UTAUT model. British Journal of Educational Technology, 1-20. https://doi.org/10.1111/bjet.12905

[24] Nunnally, J. C. (1978) Psychometric theory. 2nd Edition, McGraw-Hill, New York.

[25] Hair Jr, J. F., Sarstedt, M., Hopkins, L., \& Kuppelwieser, V. G. (2014). Partial least squares structural equation modeling (PLS-SEM). European Business Review. https://doi .org/10.1016/j.jfbs.2014.01.002

[26] Wherry, R. J. (1931). A new formula for predicting the shrinkage of the coefficient of multiple correlation. The Annals of Mathematical Statistics, 2(4), 440-457. https://doi .org/10.1214/aoms/1177732951

[27] Hair, J. F., Hult, G. T. M., Ringle, C., \& Sarstedt, M. (2017). A primer on partial least squares structural equation modeling (PLS-SEM) (2nd ed.). Thousand Oaks, United States: Sage publications

[28] Cohen, J. (1988). Statistical power analysis for the behavioral sciences. 2nd ed. Hillsdale, NJ: Lawrence Erlbaum Associates. https://doi.org/10.1002/bs.3830330104

[29] Qureshi, M. I., Khan, N., Hassan Gillani, S. M., \& Raza, H. (2020). A systematic review of past decade of mobile learning: What we learned and where to go. International Journal of Interactive Mobile Technologies. 2020 Jun 1;14(6). https://doi.org/10.3991/ijim .v14i06.13479

[30] Mustapha, I., Van, N. T., Shahverdi, M., Qureshi, M. I., \& Khan, N. (2021). Effectiveness of digital technology in education during COVID-19 pandemic. A bibliometric analysis. International Journal of Interactive Mobile Technologies. 2021 Aug 1;15(8). https://doi .org/10.3991/ijim.v15i08.20415

[31] Khan, N., Qureshi, M., Mustapha, I., Irum, S., \& Arshad, R. (2020). A systematic literature review paper on online medical mobile applications in Malaysia. International Journal of Online and Biomedical Engineering, 16(1), 63-82. https://doi.org/10.3991/ijoe . $\mathrm{v} 16 \mathrm{i} 01.12263$

\section{Authors}

Mohamad Rahimi Mohamad Rosman is a senior lecturer at the Faculty of Information Management, Universiti Teknologi MARA Kelantan Branch. His research interests are information system management, user engagement, digital library, and content management.

Izzatil Husna Arshad is a senior lecturer at the Faculty of Information Management, Universiti Teknologi MARA Kelantan Branch. Her research interests are information system management and information management. 
Mohamad Sayuti Md Saleh is a finance lecturer at Universiti Teknologi MARA, Kelantan branch. He is very committed to deepening the latest knowledge whether in the field of finance, Islamic banking, entrepreneurship, and economics.

Nurulannisa Abdullah is a senior lecturer at the Faculty of Information Management, Universiti Teknologi MARA Kelantan Branch. Her research interests are electronic records management, digital repository, and cataloguing education.

Faizal Haini Fadzil is a senior lecturer at the Faculty of Information Management, Universiti Teknologi MARA Kelantan Branch. His research interests are information system management, web technologies and content management.

Mohd Zafian Mohd Zawawi is a senior lecturer at the Faculty of Information Management, Universiti Teknologi MARA Kelantan Branch. His research interests are information system management and user competencies.

Article submitted 2021-06-04. Resubmitted 2021-07-22. Final acceptance 2021-07-23. Final version published as submitted by the authors. 